\title{
“This Is Attested Truth" The Rhetoric of Truthfulness in Early Modern Broadside Ballads
}

\section{Nicolas Moon}

If we are to judge by the interest they aroused in the London publishing industry, there were extraordinary sights to behold in Cork in 1621, sights that inspired several pamphlets and at least two broadside ballads. Locals apparently witnessed the strange occurrence of "an vnusual multitude of birds called Stares" (starlings), who gathered near the city of Cork in order to:

fight together the most bitterest and sharpest battell amongst themselues, the like, for the manner of their fight, and for the time the battell did continue, neuer heard or seene at any time in any Country of the world. ${ }^{1}$

In an address to the reader, the pamphlet which supplies these details, The Wonderfull Battell of Starelings, complains about other accounts of this spectacular sight:

so many poeticall fictions haue of late passed the print, that they [i.e. the pamphlet's audience] haue some cause to suspect almost euery extraordinary report that is printed. ${ }^{2}$

In contrast to these "fictions," the pamphlet's narrative should be accepted as truthful since its author is in possession of:

Letters, from Right Honorable persons in Ireland where the accident fell out, to Right Honourable persons at Court, and diuers in London at this present: as also by the testimony of Right Honourable and Worshipfull persons, \& others of good reputation now in London, who were eye-witnesses. $^{3}$

1 [Anonymous.], The Wonderfvll Battell of Starelings: Fought at the Citie of Corke in Ireland, the 12. and 14. of October last past. 1621. As it hath been credibly enformed by diuers Noblemen, and others of the said Kingdome, \&c. (London: for N. B., 1622), Early English Books Online (hereafter EEBO), accessed 3 February 2012, sig. A3v.

2 Ibid., sig. A2 ${ }^{\mathrm{v}}$.

3 Ibid., sig. A2v 
It is hard not to suspect that, amidst the generic complaint at the quality of sensational publishing (a common technique for asserting a writer or text's own credit by comparison), the pamphlet is concerned with a particular ballad. A battell of Birds - or to give the ballad its full title, A battell of Birds, Most strangly fought in Ireland, upon the eight day of September last, 1621. where neere unto the Citty of Corke, by the river Lee, weare gathered together such a multytude of Stares, or Starlings, as the like for number, was never seene in any age - provides an abbreviated account of the same events. ${ }^{4}$ It is easy to imagine that the pamphlet's criticism is implicitly directed at this alternative narrative owing to discrepancies in their accounts, not least the fact that they disagree on exactly when this incredible avian war is supposed to have taken place. Yet, as its closing stanza makes clear, the ballad manifests the same anxiety, equally concerned to establish its status as a truthful account, and its content as news that is worthy of a receptive audience: "What now for trueth is publisht forth | esteeme it as a newes of worth" (1. 103-104).

These truth claims, and the types of reliability claimed by both texts, are central to the concerns of this chapter. Present in both pamphlet and ballad versions of this narrative is a concern with sight. This extraordinary occurrence is defined as something which has been seen, and which can be recounted and understood only thanks to the presence of eyewitnesses. It is through the testimony of trusted individuals that the truth of this fantastical sight can be guaranteed. The basis of the ballad's truth claims is also the very fact of its having been "publisht forth," an ambiguous phrase that relates to a ballad's dual status as both an oral and printed text. The ballad is "publisht" therefore both in the sense that it is proclaimed and makes its narrative known, and in the sense that it is also disseminated to its audience through the medium of print. It implies that part of the reason the ballad should be accepted by its audience as "newes of worth," both truthful and worth knowing, lies in its being a printed, and widely circulated, text.

Ballads that provide accounts of official or military events, natural catastrophes, or miraculous happenings, appear to have a greater concern to declare and authenticate their veracity than do other examples of popular song. If an event is labelled as 'news', it not only prompts the interest of its audience within a particular context, but declares that the reported events actually occurred, and that the account being offered is truthful and reliable. Any news text, whether newspaper or ballad, contains not only linguistic but paratextual

4 [Anonymous], A battell of Birds (London: W. I[ones], 1621), EEBO, accessed 8 February 2012; Hyder E. Rollins (ed.), A Pepysian Garland (Cambridge, MA: Harvard University Press, 1971), pp. 150-154. 
and social rhetorics which attempt to establish its truthfulness. It is obviously impossible to know the full extent to which such truth claims would have been believed by a contemporary audience. When Will Kemp disparages the "lying ballets" which he believes have defamed him in his pamphlet Nine Daies Wonder, his concern with his reputation is clearly partly a response to the anxiety that such lies might have been believed by the audience to which he is addressing in his text. ${ }^{5}$

This chapter explores the range of truth claims that were available to the readers of Early Modern news ballads, which aimed to establish the truth of their accounts of a variety of events deemed 'news-worthy' by the broadside trade. Whilst acknowledging the significance of the material text, recent work on ballads has tended to privilege the ballad as an inherently spoken or oral genre, with the printed text largely reduced to the status of a 'container'.6 In contrast, the effectiveness of many of the markers examined in this chapter is clearly the product of print. Purely in terms of the numbers produced, broadside ballads must have been one of the most widely available printed sources for news in early modern England, accessible to a broad audience owing to their relative cheapness. ${ }^{7}$ Occupying a position between oral and printed media, simultaneously spoken and written, and at least by the early seventeenth century employing images alongside their narratives, the contents of broadside ballads covered a wide range of subject matter, with what has been identified as the journalistic or 'news ballad' outnumbering all other types. ${ }^{8}$

5 William Kemp, Nine Daies Wonder (1600), ed. by George B. Harrison (Edinburgh: Edinburgh University Press, 1966), p. 30.

6 See Christopher Marsh, Music and Society in Early Modern England (Cambridge: Cambridge University Press, 2010), pp. 225-327; Bruce Smith, The Acoustic World of Early Modern England: Attending to the O-factor (Chicago: Chicago University Press, 1999), pp. 168-205.

7 Tessa Watt has plausibly estimated that up to 4,000,000 ballads could have been printed by 1600; Cheap Print and Popular Piety, 1550-1640 (Cambridge: Cambridge University Press, 1990), p. 11. Purchasing a broadside was of course not the only way in which an early modern subject might conceivably come into contact with ballads, since broadsides were liable to be passed around any given community, pasted up upon walls, and circulated through oral communication.

8 Pepysian Garland, p. xi. Angela McShane has persuasively argued that the term 'news ballad' is an anachronism, the product of modern criticism, and has proposed the more taxonomic term of 'political ballad' for those ballads whose content is about one of what she defines as the "four basic axes, royal events; military affairs; punishment of traitors and rebels and foreign events where Protestantism was seen to be under threat from Papist or Turk." In arguing that ballads were 'timeless' in their concerns, McShane relies on an assumption which sees 'information' as the sole concern of news, while ballads are reduced to the role of "putting an 
Famously, the possibility that print could be viewed as a guarantor of a ballad's truth claims is mocked in a scene from Shakespeare's The Winter's Tale. When confronted with the ballads offered for sale by the roguish ballad seller Autolycus, the innocent shepherdess Mopsa responds with the naïve statement, "I love a ballad in print, a life, for then we are sure they are true."9 Adrian Johns has argued that the conviction that print was a guarantor of truth and reliability was one that initially had to be constructed by the early modern print trade in the face of considerable evidence to the contrary. ${ }^{10}$ Printers and booksellers pursued a number of strategies to attest to the 'credit' and reliability of their various publications. As this chapter's opening examples indicate, this was a concern also demonstrated by what might be considered less creditworthy works such as short pamphlets and broadsides, genres whose credibility was often called into question. ${ }^{11}$

Broadside ballad truth claims are chiefly situated in their titles and other paratexts. The simplest way for a ballad title to argue for the veracity of an event is to claim that it is true. A claim to be a 'true report' or description appears in many titles, typically when describing sensational or fantastical occurrences:

The true reporte of the forme and shape of a monstrous Childe borne at Muche Horseleye, a village three myles from Colchester, in the Countye of Essex, the xxi daye of Apryll in this yeare 1562.12

argument via a moral gloss or emotional response" on an essentially oral news culture. As this chapter demonstrates, broadside ballads were not wholly oral texts but made use of elements which were the sole preserve of print. Nor is it clear that news ballads are unusual in placing events, political or otherwise, within a preconceived moral framework. See Angela McShane Jones, "The Gazet in Metre; or The Riming Newsmonger, The English Broadside Ballad as Intelligencer: A New Narrative" in Joop W. Koopmans (ed.), News and Politics in Early Modern Europe (1500-1800) (Leuven: Peeters, 2005), pp. 131-150.

9 William Shakespeare, The Winter's Tale, ed. by John Pitcher (London: A \& C Black, 2010), iv.iv.260-261.

10 Adrian Johns, The Nature of the Book (Chicago: The University of Chicago Press, 1998).

11 Deceitfulness was merely one of the accusations made against ballads in the sixteenth and seventeenth centuries, as Natascha Wurzbach's compilation of representative views by contemporaries demonstrates. See The Rise of the English Street Ballad 1550-1650, trans. Gayna Walls (Cambridge: Cambridge University Press, 1990), pp. 242-284.

12 [Anonymous], The true reporte of the forme and shape of a monstrous Childe borne at Muche Horseleye (London: Thomas Marshe, 1562), EEBO, accessed 8 February 2012; Joseph Lilly (ed.), A Collection of Seventy-Nine Black-Letter Ballads and Broadsides, Printed in the Reign of Queen Elizabeth, Between the Years of 1559 and 1597 (London: Joseph Lilly, 1867), pp. 27-30. 
The true description of two monsterous children, lawfully begotten betwene George Steuens and Marjerie his wyfe, and borne in the parish of Swanburne in Buckynghamshyre the [4th] of Aprill, Anno Domini 1566.13

Strange News from Brotherton in Yorke-shire, being a true Relation of the raining of Wheat on Easter day last, to the great amaizment of all the Inhabitants. $[\ldots]^{14}$

Elsewhere the formula is applied to an account of military victory:

A true discourse of the winning of the towne of Berke by Grave Maurice, who besieged the same on the 12 day of June 1601, and continued assaulting and skirmishing there until the last day of July, at which time the towne was yielded. ${ }^{15}$

All four examples also demonstrate a somewhat pedantic urge, typical of many news ballads, and already illustrated by my opening example, to delineate details of place and time within their titles, so as to fix their accounts in a precise geographic and temporal space, and thereby authenticate their ballads' status as 'true' accounts.

This pedantry extends to the inclusion of apparently precise measurements. In A newe Ballad of the most wonderfull and strange fall of Christ's Church pinnacle in Norwich, the which was shaken down by the a thunder-clap on the 29 of Aprill 1601, about 4 or 5 o'clock in the after-noone: with a description of a miraculous fire, which the verye next morning consumed and burnt downe a great part of the cloyster, details provided in the fifth and sixth stanzas perform the same rhetorical function as the details of time and place present in the title: ${ }^{16}$

13 [Anonymous], The true description of two monsterous children (London: Alexander Lacy for William Lewes, 1566), EEBO, accessed 8 February 2012; Black-Letter Ballads, pp. 217-220.

14 [Anonymous], Strange Newes from Brotherton in Yorke-shire, being a true Relation of the raining of Wheat on Easter day last, to the great amaizment of all the Inhabitants. It hath rained Wheate more or lesse every day since, witnessed by divers persons of good ranke and quality, as the Lady Ramsden who gathered some her selfe, some of it was sent to Judge Green, and M. Hurst dwelling at the Fountaine Taverne in Saint Anns Lane neere Aldersgate in London (London: John Hammond, 1648), EEBO, accessed 4 June 2012; in Henry Rollins (ed.) The Pack of Autolycus (Port Washington and London: Kennikat Press, 1969), pp. 36-43.

15 [Anonymous], A true discourse of the winning of the towne of Berke by Grave Maurice in Andrew Clark (ed.) The Shirburn Ballads, 1585-1616 (Oxford: Clarendon Press, 1907), pp. 272-276.

16 [Anonymous], A newe Ballad of the most wonderfull and strange fall of Christ's Church pinnacle in Norwich in Shirburn Ballads, pp. 204-206. 
Some three score yards it was in height [...]

Above the steple, which (at least)

is fyvescore yards from ground.

The stone, which on the top thereof

(to crowne the other) lay,

Is thought to be a good Cart-loade,

as many people say.

Vpon the stone there stoode a crosse,

about three yards hye,

Which bare a stately wether-cocke [...]

The cocke was full an ell in length;

and in the breadth (full out)

Three quarters of a yarde it was;

syxe quarters ruond abovt.

ll. $37,38-46,48-52$

Where there is room for doubt about a specific detail, the wider community is appealed to as a source of authority; that "many people say" that something is true, is sufficient reason to believe in its truthfulness. Since the dimensions of the church are exaggerated, there is even something inadvertently comic in the ballad's pretensions to detailed accuracy. For an audience which lacks either access to more accurate information, or the means of testing the ballads' claims, such details function simultaneously as truth claims as well as a means to impress through their exaggerated proportions.

Designed to advertise the ballad texts, and thus possessing an effect comparable to newspaper headlines, ballad titles such as these simultaneously function as narratives in their own right. As short as these titles are, they still provide the precise details of name, place, and date which, as Helen Smith has observed in relation to early modern imprints, are "the three key indicators on which so many fictional narratives are built."17 Serving only to establish the verisimilitude of the narrative, they produce what Roland Barthes has termed "the reality effect." 18 Where a narrative consists only of these three details, Smith suggests, "the effect is one of absolute verisimilitude:

17 Helen Smith, "Imprinted by Simeon such a signe': Reading Early Modern Imprints" in Helen Smith and Louise Wilson (eds.), Renaissance Paratexts (Cambridge: Cambridge University Press, 2011), pp. 17-33 (p. 28).

18 Roland Barthes, "The Reality Effect" in Tzvetan Todorov (ed.), French Literary Theory Today: A Reader, trans. R. Carter (Cambridge: Cambridge University Press, 1982), pp. $11-17$. 
a reality effect which renders its rhetorical or narrative effects invisible." ${ }^{19}$ Longer titles might contain more extraneous detail, but still fulfil this basic function.

As the trade developed over the course of the seventeenth century, ballad titles tended to become longer and more elaborate, fulfilling more emphatically this fictive and accrediting role. The proliferation of elaborate titles is clearly both the creation of, and a function of, print. Thus by 1661 a ballad advertises its contents as,

A most wonderful and sad judgement of God upon one Dorothy Mattley late of Ashover in the County of Darby, within fourteen miles of the said Town of Darby; who for so small a thing as two single pennies which she was charged with the taking of from a boy, did most presumptuously with sad imprecations wish and desire, that if she had taken or stole the same, that the ground might open and she sink therein, which by her neighbours relation was an expression very common with her, but so it pleased God to deal, that upon the same words the ground did open, and she with a Tub which she was washing Lead-Oare in sunk into the ground, to the amazement of the beholders, and the ground closed again upon her, as here underneath it is more fully declared; and this was done upon the 23 of March 1660. All which may well serve for an example to all wretches of this age whatsoever, who to advance themselves by falshood, or for the trifles of this world, take to themselves assumptions, and imprecations, nay will not at all stand to forswear themselves to compass their own ends, as if there was no God or iudgment to be expected; but they may hereby take notice that some time God will punish such creatures even in this life for example sake; yet if not here, their reward will be according to their works hereafter, and none shall be able to let it. ${ }^{20}$

Unsurprisingly, the boast that "here underneath it is more fully declared," goes unfulfilled. The two hundred and fifty-two words of this extravagant title would never function successfully in oral circulation, nor could they work as a simple headline, to be read quickly and capture the imagination. Detached from the ballad that it nominally announces, it functions quite successfully as a narrative of the events of which the ballad text is supposed to be informing its audience. The sixteen stanzas of the ballad serve

19 Smith, "Early Modern Imprints," p. 28.

20 [Anonymous], A most wonderful and sad judgement of God upon one Dorothy Mattley (London: W. Gilbertson, 1661), EEBO, accessed 8 February 2012. 
only to recapitulate at slightly greater length a narrative that is already known.

In his analysis of the relationship between the broadside ballad and its title, Mark Booth has argued that this repetition is precisely the point, and compares ballads specifically to sensationalist journalism. The intention of such journalism is not to inform its audience of news and convey information, but rather to retail sensation, and the excitement of being part of a community that responds to a particular event in a specific manner. It is unlikely that many people would purchase a ballad in order to learn about news; rather, reading or repeating the ballad - texts that were, after all, generally sold through performance - offers a means of taking possession of existing information, of confirming what the audience already knows. ${ }^{21}$ According to Booth's analysis of Martin Parker's A description of a strange (and miraculous) Fish, ${ }^{22}$ the news ballad's text does nothing more than recapitulate the single point that what it is describing is a "monstrous," and very big, fish. It offers its audience nothing more than the repeated and varied certainty that the fish in question was huge. The printed broadside becomes a means of taking possession of the experience of the thing that is being described at such length, rather than learning anything of substance about it. ${ }^{23}$ Similarly, despite superficially more serious concerns, the ballad about Dorothy Mattley is equally concerned with sensation in bringing the account of God's retribution to the attention of its audience, reiterating both the news of Mattley's punishment, and the providential 'news' of God's responsive omnipotence. Indeed, the framework within which virtually all news ballads situate their narratives is a popular providential discourse. $^{24}$

Another, more visible, sign of ballad titles' rhetorical effects is shown in titles which, instead of boldly proclaiming their truthfulness, signal their truth claims by identifying the emotional response they expect from their audience. Most commonly this reaction is a lamentation, whether the news is an account

21 For details of ballad-selling techniques and performance see Marsh, Music and Society, pp. 225-288; Smith, Acoustic World, pp. 168-205; Wurzbach, English Street Ballad, pp. 39-101.

22 Martin Parker, A description of a strange (and miraculous) Fish, cast upon the sands in the meads, in the Hundred of Worwell in the County Palatine of Chester, (or Chesshiere[)]. The certainty whereof is here related concerning the said monstrous Fish (London: Thomas Lambert, 1636); Pepysian Garland, pp. 438-442.

23 Mark Booth, The Experience of Song (New Haven and London: Yale University Press, 1980), pp. 103-109.

24 See Alexandra Walsham, Providence in Early Modern England (Oxford: Oxford University Press, 1999). 
of murder, for example The unnaturall Wife: Or, The lamentable Murther, of one goodman Davis, Locke-Smith in Tutle-streete; ${ }^{25}$ events of wider political import, such as A lamentable Ditty composed upon the Death of Robert Lord Devereux, late Earle of Essex; ${ }^{26}$ or the description of natural disasters, as in The lamentable Burning of the Citty of Corke (in the Prouince of Munster in Ireland) by Lightning: which happened the Last of May, $1622 .{ }^{27}$ This latter also functions as a sequel to Battell of the Birds, describing the events for which those of the earlier text were interpreted as an omen. More local concerns might similarly be described in terms that provoke sorrow or sad contemplation, as in $A$ dolefull dittye of five unfortunat persons that were drowned in their drunknes in crossing over the Thames neare Iry Bridge. ${ }^{28}$

The audience's emotional response is also directed within the ballad text. This last ballad of drunken calamity at Ivy Bridge, for example, opens with the assertion, "What hart so hard, but will relent | of Strangers' suddaine death to heare" (ll. 1-2). Similarly, A newe Ballad of the most wonderfull and strange sight of Christ's Church pinnacle in Norwitch begins by asserting:

If ever words did moue a wight

to shed a wofull teare,

Then can no creature choose but weepe,

this dolefull tale to heare.

ll. $1-4$

25 [Anonymous], The vnnaturall wife: or, The lamentable murther, of one goodman Dauis locke-smith in Tutle-streete, who was stabbed to death by his wife, on the 29. of Iune, 1628. For which fact, she was araigned, condemned, and adiudged, to be burnt to death in Smithfield, the 12. Iuly 1628 (London: M. T[rundle], 1628), EE BO, accessed 8 February 2012.

26 [Anonymous], A lamentable dittie composed vpon the death of Robert Lord Deuereux late Earle of Essex who was beheaded in the Tower of London, vpon Ashwednesday in the morning. 1601 (London: Margaret Alde, 1603), EEBO, accessed 8 February 2012; William M. Chappell and Joseph W. Ebsworth (eds.), The Roxburghe Ballads, 9 vols (London: The Ballad Society, 1869-1901), vol. 2, pp. 202-211.

27 [Anonymous], The lamentable Burning of the Citty of Corke (in the Prouince of Munster in Ireland) by Lightning: which happened the Last of May, 1622. After the prodigious Battell of the Stares, | which Fought most strangely ouer and neere that Citty, the 12. and 14. of May. 1621 (London: E.A., 1622), EEBO, accessed 8 February 2013; Pepysian Garland, pp. 155-160.

28 [Anonymous], A dolefull dittye of five unfortunat persons that were drowned in their drunknes in crossing over the Thames neare Ivy Bridge, upon sundaye night the 15 of October last, 1616: set forth for an example for all such prophaners of the Lord's Sabaoth daye in Shirburn Ballads, pp. 68-71. 
Specifying an audience's correct emotional response either in the title or opening stanza is inherently more subjective. It becomes a promise that the ballad's narrative will satisfactorily evoke this emotional quality. 'Truth' here is attested through a quality of feeling, bolstering ballad claims to be considered as truthful accounts through the fulfilment of an aesthetic quality.

The emotional content of ballads could also be supported by the choice of tune. Christopher Marsh has written most extensively on the role which the ballad tune played in the ways in which ballads might have been received by their audience, with melodies "capable of reinforcing, altering and destabilising textual messages." ${ }^{29}$ Where a news ballad is set to a sober tune such as "Packington's Pound" or "Fortune My Foe" (also popularly known as the "hanging tune"), the importance of its message would be underlined by the tune to which it was sung. Equally, where "Fortune my Foe" was the tune direction for the apparently celebratory ballad, A joyful new ballad of the late victorye obtained by my Lord Mount Joy and our Maiestie's forces in Ireland, against that archtraytor Tirone and confederates, upon the 24 of December last, the emotional response specified by the title would appear to be in conflict with the choice of a doleful tune: ${ }^{30}$

England, giue prayse vnto the Lord thy god, the which in mercye doth withhold the rod From vs, whose synnes deserued haue the same: yet we continwe, Sodome-like, past shame[...]

ll. $1-4$

As the ballad's opening lines make clear, the credit for this military victory and for defending the English nation from its enemies, is granted to God, to whom the unreformed nation should turn in thanks for their victory.

As well as the title, some ballads also employed postscripts, a short prose section placed after the main ballad text, which would never have been intended to be sung, and which explicitly foregrounds their claims to truthfulness and authority. In The Winter's Tale, as proof of his ballads' truthfulness, Autolycus offers the signatures of "one Mistress Tale-Porter, and five or six

29 Marsh, Music and Society, p. 289.

30 [Anonymous], A joyful new ballad of the late victorye obtained by my Lord Mount Joy and our Maiestie's forces in Ireland, against that archtraytor Tirone and confederates, upon the 24 of December last. Also of the yeeldinge of the Towne of Kingsalt, with 3 or 4 other houldes, by Don John at Aquila, Generall of the Spanish army, which was yielded by the 9 of January last 1602 in Shirburn Ballads, pp. 124-128. 
honest wives that were present,"31 or "Five justices [...] and witnesses more than my pack will hold." ${ }^{32}$ The copies of the signatures of which the ballad seller boasts are clearly not part of the text that would be sung by the ballad's purchaser. Either they might appear as part of the ballad's title, or more likely they are part of a postscript. Significantly, they are something that Autolycus shows to his onstage audience of potential customers, a visual signifier of the text's truth claim. An example of the simplest form of postscript, akin to the signatures offered by Autolycus, is found at the end of The lamentation of Henrye Adlington, one of the cutting crewe of London, where it states that the ballad contains the words of "Harrye Adlington, made with his owne hand in the Marshalsye, after his condemnation" (ll. 73-74). ${ }^{33}$ This example, like many 'goodnight' ballads, provides a striking example of Bruce Smith's assertion that "what ballads offer the singer and the listener is the possibility of becoming many subjects, by internalizing the sounds and rhythms of those subjects' voices." 34 In this case, the reader or performer is reminded that they have ventriloquized or occupied the subject position of a condemned man, speaking effectively in the exemplary voice of the corpse that hangs at Aldgate.

Other versions of the postscript are oriented to providing authoritative proofs. News out of East India, which recounts the massacre of English colonists and destruction of their settlement at Cambello on the island of Amboyna by the Dutch in 1623, provides two lists of names. In one column are the names of those who were executed, whilst the names of those who were pardoned by the Dutch appear in the other. ${ }^{35}$ Their individual names act as a referent, signifying the truth of the gruesome events described in the main ballad text. The same effect is achieved in Thomas Deloney's A proper new ballad breefley declaring the Death and Execution of fourteen most wicked Traitors, where the postscript supplies the names of all fourteen traitors. ${ }^{36}$ Somewhat more

31 Winter's Tale, iv.iv.269-271.

32 Ibid., iv.iv.283-284.

33 [Anonymous], The lamentation of Henrye Adlington, one of the cutting crewe of London, who, for murther, was executed without Aldgate, and yet hangeth in chains in Shirburn Ballads, pp. 106-108.

34 Smith, Acoustic World, p. 201.

35 [Anonymous], Nevves out of East India of the cruell and bloody vsage of our English merchants and others at Amboyna, by the Netherlandish gouernour and councell there (London: F. Coules, 1624), Е вво, accessed 3 June 2012; Pepysian Garland, pp. 201-206.

36 Thomas Deloney, A proper new ballad breefley declaring the Death and Execution of fourteen most wicked Traitors, who suffered death in Lincolnes Inne feelde neere London: the 20 and 21 of September, 1586 (London: Edward Alde, 1586), EEBO, accessed 3 June 2012; 
whimsically, the Ivy Bridge ballad includes a list of "The professions of these persons, so vnfortunately drowned" (1l. 121-123), these being a haberdasher, a tailor, a saddler, a barber, and a waterman. This mundane list of professions links the unfortunate persons whose deaths the ballad records with the ordinary concerns of the ballad audience, and produces a sense of verisimilitude, though perhaps also of exemplarity, as it takes in a cross-section of city traders, producing an effect of universal (or at least London mercantile) applicability.

The postscript of A discription of a monstrous Chylde, bourne at Chychester in Sussex, works in a similar manner, identifying the profession of the child's father, and stressing the moral worth of both parents:

The father hereof is one Vyncent, a boutcher, bothe he and hys wyfe being of honest \& quiet conuersation. They hauing had chyldre before, in natural proportion; and went with this her full tyme. ${ }^{37}$

The postscript is part of the ballad's engagement with popular Reformation hermeneutic practices, which attempted to read such monstrous children as evidence of God's role within the world. ${ }^{38}$ However, it also serves as a purely literal sign that validates the child's existence in the world against any claims that might be made about the fabulous nature of the child. Nature's Wonder?, another ballad about a monstrous child from 1664, with a full title nearly as long as the earlier ballad about Dorothy Mattley, gives its postscript its own title, "A true Relation of this strange and wonderfull MONSTER" (1. 97). ${ }^{39}$

Thomas Mann (ed.), The Works of Thomas Deloney (Oxford: The Clarendon Press, 1912), pp. 464-468.

37 [Anonymous], A discription of a monstrous Chylde, borne at Chychester in Sussex, the .xxiiii. daye of May. This being the very length, and bygnes of the same (London: Leonard Askel for Fraunces Godlyf, 1562), EEBO, accessed 3 June 2012; Black-Letter Ballads, pp. 201-204.

38 See Helaine Razovsky, "Popular Hermeneutics: Monstrous Children in English Renaissance Broadside Ballads," Early Modern Literary Studies, 2.3 (1996), 1.1-34.

39 [Anonymous], Nature's Wonder? OR, [An ac]count how the Wife of one John Wate[...]man an Ostler in the Parish of Fisherton-Anger, near Sali[s]bury, was Delivered of strange Monster upon the 26th. of October 1664. which lived untill the 27th. of the same Moneth. It had two Heads, foure Armes, and two Legs. The Heads standing contrary each to the other; and the Loines, Hipps and Leggs Issueing out of the middle, betwixt both. They were both perfect to the Navell, and there joyned in one, being but one Sex, which was the Female. She had another Child born before it (of the Female Sex) which is yet living, and is a very comely Child in all proportions. This is Attested for truth, by several Persons which were eye wittnesses (London: E. Andrews, 1664), EEBO, accessed 8 February 2013; Pack of Autolycus, pp. 140-145. 
This repeats information about the names and occupations of the child's parents, a physical description of the child, and details of its place of birth, all of which has already been given in the ballad title. The only new information it supplies at the tail end of this text are details of the witnesses who saw this child:

There hath been both Lords, Ladys, and much Gentry to see it; The Father (being a poore man) had twenty pound given him the first day, by persons of Quality. I Josiah Smith, Practitioner of Phisick, saw them all three alive.

The visitors' value as witnesses is explicitly tied to their social status and profession, whether they are members of the "Gentry" or "Practitioner[s] of Phisick." The presence of Josiah Smith places this ballad, and the monstrous child which is at its heart, within a medical discourse which advertises the body of the child as an object of curiosity: "This Monster lived two days and then dyed, and is Imbalmed, and to be brought to London to be seen" (ll. 105106). As the title of one news ballad makes clear, the function of such narratives is "[ $t]$ ruth brought to light." ${ }^{40}$ In the form of a printed broadside, the news is, like the child of Nature's Wonder? an object to be seen and examined.

As has already been noted, the majority of news ballads invoke a providential reading in order to explain the events and prodigies they describe. Certainly within the ballad text, if not within their titles, the use of the word "warning" signifies their providential import: for example, A Warning for all Murders, A most rare, strange, and wonderful accident, which by God's just judgement was brought to pass, not farre from Rithin in Wales, ${ }^{41}$ or $A$ warning to London by the fall of Antwerp. ${ }^{42}$ By labelling themselves as a "warning," ballads are basing their authority, and thus their truth claims, on that of divine providence. In the

40 [Anonymous], Truth brought to light, or, wonderful strange and true news from Gloucestershire, concerning one Mr. William Harrison, formerly stewart to the Lady Nowel of Cambden, who was supposed to be murthered by the widow Pery and two of her sons (London: Charles Tyus, 1662), EE EO, accessed 6 June 2012; Pack of Autolycus, pp. 96-100.

41 [Anonymous], A warning for all murderers A most rare, strange, and wonderful accident, which by Gods just judgement was brought to passe, not farre from Rithin in Wales, and showne upon three most wicked persons, who had secretly and cunningly murdered a young gentleman named David Williams, that by no meanes it could be knowne, and how in the end it was revenged by a childe of five yeeres old, which was in his mothers wombe, and unborne when the deed was done (London: Henry Gosson, 1620), EEBO, accessed 6 June, 2012.

42 Rafe Norris, $A$ warning to London by the fall of Antwerp (London: John Allde, 1577), EEBO, accessed 6 June 2012. 
case of $A$ warning to London, this didactic purpose obscures any value the ballad might have as news. The warning represented by the fall of Antwerp is apparently a reference to the sacking of Antwerp by Spanish troops in November 1576, information about which is absent from both ballad title and text. Instead the ballad is concerned with a didactic appeal to the people of England to "Forsake thy Deuilish drunken trade" (1. 29). Antwerp appears only as a threat for what may happen if the English people fail to repent, a fact with which it assumes its audience is already conversant. In this respect, $A$ warning to London by the fall of Antwerp is actually at the other extreme from many of the ballads discussed in this chapter, since by gesturing to a reality beyond its page, the audience can only infer from its reference to "Antwerp" that it is interfacing with an oral culture; that it is part of a conversation around a shared object of knowledge.

Visually however, the ballad still employs the techniques made available by print, adorned both with a picture and an elaborate border. To date, criticism of the broadside picture has tended to follow Natascha Wurzbach's dismissive statement that the woodcuts employed by many ballads were "a crude affair [...] which resulted not infrequently in a crass incongruence between illustration and text." 43 More recently, Malcolm Jones has characterized ballad images' "generic' relevance" to the texts they illustrated as "notorious." 44 The assumption has been that the ballad picture served a purely decorative function, a means of facilitating sales, and that ballads often employed mismatched images from a common stock. Although not all critics have been so dismissive of the ballad picture, ${ }^{45}$ it has still tended to be an element relegated to secondary or even tertiary importance after the ballad text and tune. Many images, however, were newly cut for ballad publication. ${ }^{46}$ Even in instances where images have clearly been reused from a common stock, some printers, or perhaps their commissioning booksellers or authors, made considerable effort to try to match an appropriate image to the ballad text. It is conceivable that the woodcut image that adorns the broadside of $A$ Warning to London (see Fig. 12.1) is a crude attempt at representing the city of Antwerp, but even if it is only a

43 Wurzbach, English Street Ballad, p. 9.

44 Malcolm Jones, The Print in Early Modern England: An Historical Oversight (New Haven and London: Yale University Press, 2010), p. 5.

45 See Patricia Fumerton, "Not Home: Alehouses, Ballads, and the Vagrant Husband in Early Modern England," Journal of Medieval and Early Modern Studies, 22.3 (2002), pp. 493518; Angela McShane, "Subjects and Objects: Material Expressions of Love and Loyalty in Seventeenth-Century England," Journal of British Studies, 48. 4 (2009), pp. 871-886, at 878-884; Watt, Cheap Print, pp. 131-216; Smith, Acoustic World, pp. 204-205. 


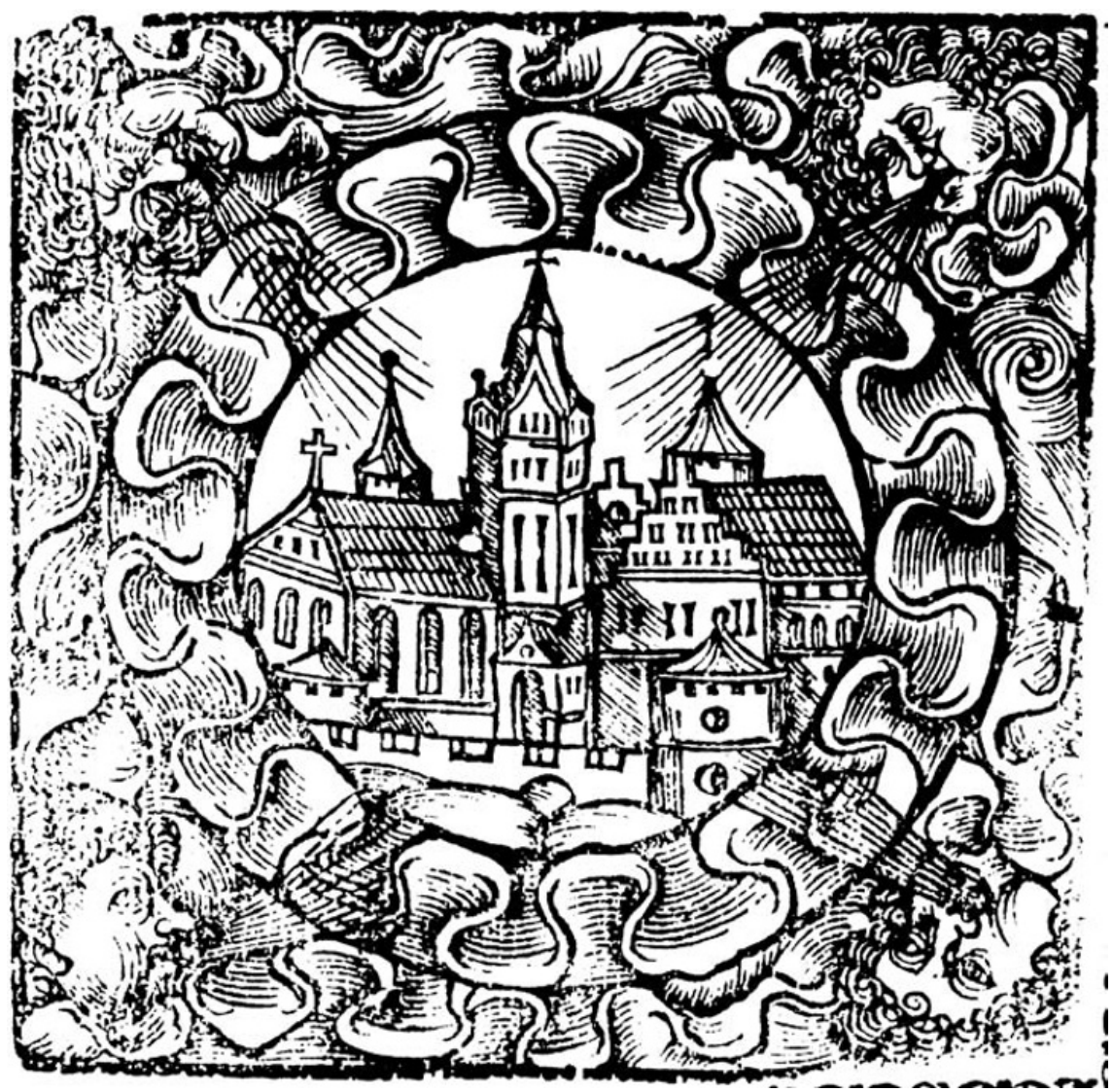

FIGURE 12.1 Rafe Norris, A warning to London by the fall of Antwerp (London:John Allde, 1577).

This item is reproduced by permission of The Huntingdon Library, San Marino, California. Rв 18324.

'generic' image of an urban context, its imagery still matches the ballad's argument. The four figures surrounding the city, representing the buffeting winds, are consistent with the metaphors employed in the ballad's argument that London needs to 'stand fast' against the threatening forces surrounding it, lest it should suffer the same fate as its exemplar.

Another attempted match between ballad image and text is found in the ballad, A Wonderfull wonder: Being a most strange and true relation of the resolute life and miserable death of Thomas Miles. ${ }^{47}$ Miles died by choking to death

47 L.P., $A$ wonderfull vvonder, being a most strange and true relation of the resolute life, and miserable death of Thomas Miles, who did forsweare himselfe, and wished that God might 


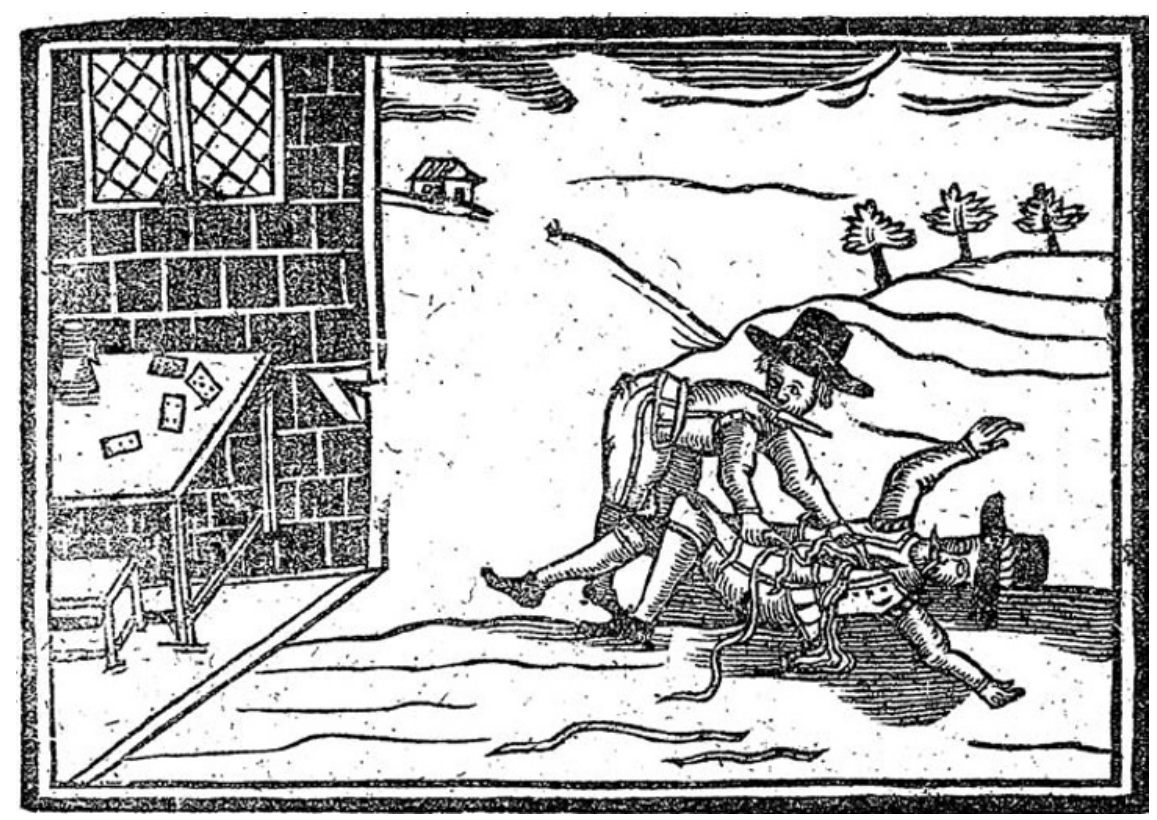

FIGURE 12.2 L.P., A wonderfull vvonder, being a most strange and true relation of the resolute life, and miserable death of Thomas Miles... (London:John Wright junior, 1635). (C) THE BRITISH LIBRARY BOARD HUTH 50[30].

at table after uttering blasphemies against God (see Fig. 12.2). His corpse was, apparently, cut open by surgeons at St. Bartholomew's hospital, who discovered that he had choked on a "gub of meate" (1. 46). The ballad opens by appealing to God, "Looke down, O Lord, upon this sinfull land!" (1.1), establishing that it is sight which allows God to discern human wrongdoing. A more human investigation is described in the ballad's eleventh stanza:

the surgeons tooke in hand

To rip him up, that they might understand

The truth and reason how he lost his breath,

And how he came by his untimely death.

ll. $41-44$

shew some heavie example upon him, and so it came to passe for as hee sate at his meate hee choked himselfe, and died in short space after, which hapned the 8. of August last, 1635. and being ript up by the chirurgions of S. Bartholomewes Hospitall, was found to have a gub of meate sticking fast in his throate, which was the cause of his death. Written to warne all rash swearers to forsake their evill wayes, which God grant we may (London: John Wright junior, 1635), ЕEBO, accessed 6 June 2012. 
In this context the image above it, which is much more likely to be a representation of a murder, here stands in as a representation of the surgeons' examination, identified as such by the ballad. It represents an opening of the body to the agency of human sight, an operation carried out by "Men of good credit" (l. 50 ), paralleling the means by which God spies out wrongdoers and the providential reading of events which the ballad foregrounds throughout.

The anxieties about an event's truthfulness which are, as noted above, signalled by a stress on both the existence of witnesses and their moral worth, emphasizes how most of the paratextual devices employed by ballads to bolster their truth claims purport to be substitutes for vision; it is only through sight - through direct witnessing - that 'true events' can be perceived. With their emphasis on the thing that is being perceived, ballads about monstrous children give perhaps the clearest relationship between text and image, most markedly highlighting their status as printed objects. As the title of one monstrous child ballad has it, it offers its audience not a text or a description, but "The true fourme and shape" of monstrosity ${ }^{48}$ Similarly, the full title of the aforementioned Discription of a monstrous Chylde, boasts that it is "the very length, and bygnes of the same." This refers not to a description contained in the ballad text, since there is none, but to its picture (see Fig. 12.3). The ballad text is concerned to moralize the meaning of this monstrous birth, referring to the appearance of the child in passing, in lines which clearly relate the truth status of the ballad to its medium: "But here thou haste by Printing arte | A signe therof to se" (ll. 61-62). Without the aid of the arts of printing, there would be nothing for the audience to see. The "signe" of the illustration substitutes for the act of witnessing, and indexes the 'truth' of its referent as a visible, and quantifiable, object. Evidence that broadsides functioned as visual objects as well as a medium for the transmission of an oral text is clear from reports of broadsides being pasted to walls as decoration. ${ }^{49}$ The audience is thus invited to repeat, or participate in, the act of witnessing and attestation that the ballad describes.

Critics have frequently noted how the shepherdess Mopsa naively equates print with truthfulness in The Winter's Tale. ${ }^{50}$ The ballads offered for sale by Autolycus give examples of many of the same devices that have been examined

48 William Elderton, The true fourme and shape of a monstrous Chyld, Which was borne in Stony Stratforde, in North Hampton shire. The yeare of our Lord, M.CCCCC.LXV. (London: Thomas Colwell, 1565), E EBO, accessed 6 June 2012; Herbert L. Collman (ed.), Broadsides \& Ballads chiefly Of the Elizabethan Period (New York: Burt Franklin, 1971), p. 113.

50 For example, Smith, Acoustic World, p. 187. 


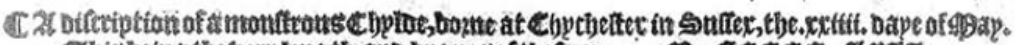
This betug the bect length, ano byenes of thefame.

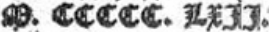

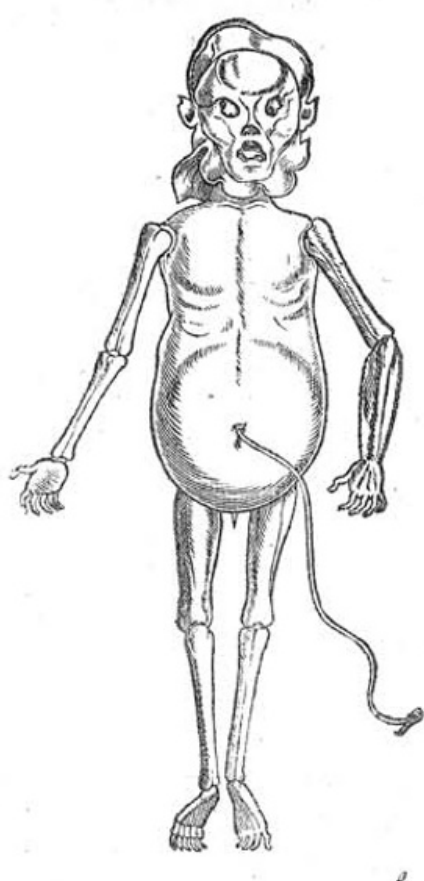

1 5en dob fos feume, to plege batb mat Mithougho, be longe oefaroe So miale bes foes a storaunge batb tent

CStat tber thereby, might tahe remouce Drtbere yit lyfe mifpent

go wioge of loure, thenif feare on fores Elocir fomall fautes repent.

Xeclose the eartb inas ouerflotoen otith waters buge tbzougbout cefrint thent goc, that boly one drith oaple tvest about.

Co calt tbem tben, to Eoolp Ipre at tobouic tibev laugbte anto funros ac lois contentes of man and fopfe Epll they toere all cenfmare.

a sto sio peracbe noof carneatly but it oto not p;cuapl-

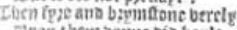
cipon t bent bounc bio barte.

Fbarasoes beart bas no remo:ete Ebougb wountores fraungc be fafto att ratber bas therfo;e the boyes caitbout all feare 0? ator.

cantyll botbe be ano bis tberfo;e

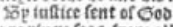

3n raginge feas, tocre all follore Sino tben be felt tbe rob.

Een tyntes truelp fore the 3ctwes In captine brougbt ano loo Berouc ctbe fyme, it đas oid bie Ded tolsens trange foeres.

\section{The peare before Jafpatian came
Ebe jetwes a bepfer ose⿰亻 et bictbe bepnge flapne, ois calue a lane Ebis fegnetber fonc bio weel. \\ Is otbers bot, and fifll baue bone} 3n ntaking it as bayne

Diels gooo lucke, thep fape foal come gis pleafe tbeir foolito b aagne.

ICbc Deathen couls fosefe ano fage Iibat twben fuche toounbers ber: 3t oio fojeflyetw to them allwayc Ebat fome pll bap ozelo nere.

Tebe feripture fapth, befo;e the enoe G) fall tbinges fyall appeare SoD foill ivounoers ftraunge tbinges fenbe as fome is fene tbis yeare.

Tbe felpe infantes, bop oe of baype Ebe Calues ano pegges fo ttraunge estitb otber mo of fucbe miflyape Declaretb tbis soo:loes cbaunge.

Wut bere, 10, fee aboue tbe reft a æonter to beboloc 9;oceoinge from a Cbrittian byeft Eo monftrous to be toloc.

Bo Caruer can, no2 papnter maps Ebe fame fo ougle matte as boetb it felf focive at tbis baye a figbt to matie the quatse.

\section{0ut berc tbou batte by printing arte a figne therof to $f e$} set eche man faye fitthin bis barte .

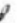

Cbat y flyouloe felte to Ique bencetoosf in Goolp Ipfe atlwape

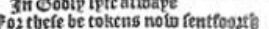
ino preacbe tbe later oaye.

glio it boeth ocutonftirate plapne ¿be great abufe ano byce Cbat bere in Cngianbe notw ooetb rapgese Ebat 9 ontrous is toe guger.

23p reabinge tlozies, fue Gall frnos In feripture, anb elles ibbere ebat foben fucbe thinges cante out af kyno

sut if foc ligbtelp toepe thefame Ano mate but nunc bapes leonoer be Lajb ont itoutucs, fone totil tame Ano barpely bange be buber.

Eben ponter foel betpures, long pat: The fequel of furbe fignes ano call to đob bp parer in baft 5rom finue to cbaunge oute menocs.

tatent, amenbe botbe bygb and lolve The lvoozoc of $\circlearrowleft 00$ embrace Co lpue therto, as fue thoulo bo: Cob geue bs all tbe grace. suob, 3bon, in

CE The fatber bereofis one Eipnernt; a bont, cher, botbe be ano bys lopec being of aon quict conuerfation. Ebev bauting bab chets ocfoze, in natural propoztion : and fuent luit tbis ber full tyme.

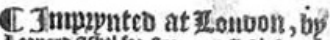

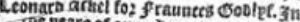

FIGURE 12.3 [Anonymous], A discription of a monstrous Chylde, borne at Chychester in Sussex, the .xxiiii. daye of May. This being the very length, and bygnes of the same (London: By Leonard Askel for Fraunces Godlyf, 1562).

(C) THE BRITISH LIBRARY BOARD HUTH 50[30]. 
throughout this chapter in a parodic form. Their titles, which give accounts of absurd events such as "how a usurer's wife was brought to bed of twenty money-bags at a burden, and how she longed to eat adder's heads and toads carbanadoed,"51 and how "a fish that appeared upon the coast on Wednesday the fourscore of April, forty thousand fathom above water, and sung this ballad against the hard hearts of maids," ${ }^{25}$ appear designed to mock their rustic audience's attempts to establish their truthfulness. The nonsensical "Wednesday the fourscore of April" ${ }^{53}$ is clearly parodying through exaggeration the apparently sincere attempts to establish a precise date found in the titles of many contemporary ballads. Likewise, the signatures offered by Autolycus burlesque the weight that genuine ballad postscripts place on the signatures they employ to signify authority and truthfulness. The extravagant events of his ballads are perhaps not so different in kind from warring flocks of birds, but his untrustworthiness is made clear to the theatre audience from his first appearance, where he presents himself as "a snapper-up of unconsidered trifles," ${ }^{54}$ and mocks his customers for their having trust in his wares: "what a fool Honesty is! and Trust his sworn brother, a very simple gentleman!"55

The Winter's Tale provides us with a double view of ballad audiences. We are faced with the rustic, onstage audience who appear happy to accept the ballads they purchase at face value, placing trust in their accounts and claims to truthfulness, however outlandish the narratives they present. Offstage, there is the urban theatre audience which is invited to laugh at the naivety of this rustic acceptance of ballads' truth claims since they know such texts to be notoriously false and a source of amusement and entertainment. No doubt, the real reception of broadside ballads, if it could be recovered, would not map so easily onto the rather simple rural/urban divide with which the play presents us. What this theatrical representation of a ballad seller shows is that there was a multitude of possible responses to ballad texts, responses which ballads in their turn responded to by providing ever more elaborate apparatuses by which their audience might establish the truth of the 'news ballad'.

The employment of such paratextual devices by broadside texts to bolster their authority and status as true accounts is clearly a result of the growing influence of the print trade, their visual effects only achievable through the medium of print. The very extravagance of some ballad truth claims, and

51 Winter's Tale, iv.iv.262-265.

52 Ibid., iv.iv.275-278.

53 Ibid., iv.iv.276-277.

54 Ibid., iv.iii.26.

55 Ibid., iv.iv.600-601. 
the proliferation of markers intended to assure readers, singers, and viewers of their authenticity, encourages modern critics almost universally to ally themselves with the clear-sighted, urban elite conjured by Shakespeare's play, imagining a playful self-awareness in place of what might just as easily be read as a deeply felt sincerity. To do so, however, is potentially to lose sight of the ways in which early modern 'news ballads' were part of a culture which was both highly invested in providential discourses and increasingly concerned to establish the authenticity of their accounts. Best viewed as a form of multimedia text which combined oral and print modes of dissemination and communication, the 'news ballad' was a genre which enthusiastically and creatively embraced the credit inherent in printed texts, the satisfaction of aesthetic qualities, and a sense of divine order to produce a compelling series of truthevents, which inextricably yoke together the wonderful and the mundane, the urgency of proof and the requirement for belief. 